\title{
Characterizing the fitness cost of viral escape from the HIV-1 broadly neutralizing monoclonal antibody VRC01
}

\author{
RM Lynch ${ }^{*}, \mathrm{~L} \operatorname{Tran}^{1}, \mathrm{X} \mathrm{Wu}^{1}, \mathrm{Y} \mathrm{Li}^{2}, \mathrm{~B} \mathrm{Lee}^{3}$, J Mascola ${ }^{1}$ \\ From AIDS Vaccine 2012 \\ Boston, MA, USA. 9-12 September 2012
}

\section{Background}

The receptor-binding site on the HIV glycoprotein gp120 is a highly conserved epitope, and certain antibodies directed against this CD4 binding site (CD4bs) can potently neutralize the majority of circulating HIV-1 isolates. One such antibody, VRC01, was isolated from a slow progressor HIV-1 infected donor who maintained low to moderate viral load without treatment. We recently described that almost all viruses in this donor plasma had escaped VRC01 neutralization. This raised the question of whether viral escape from a broadly reactive CD4bs antibody results in reduced affinity for CD4 and thus, a fitness cost to viral replication.

\section{Methods}

Env-pseudoviruses and infectious molecular clones (IMC) were constructed using near-full length gp160 env genes from three circulating VRC01-resistant viruses and their complementary revertants (where VRC01-sensitivity was restored through mutations in the CD4 binding loop, Loop D and V5) as well as from autologous env genes from the VRC01 donor (both sensitive and resistant to VRC01 neutralization). Cell entry was quantified by infectivity into cell-lines expressing varying levels of the CD4 receptor, and replication kinetics of IMC were assessed by in vitro infection of primary CD4 $\mathrm{T}$ cells.

\section{Results}

Two of the three reverted VRC01-sensitive viruses demonstrated more efficient CD4 receptor mediated entry and greater replication in CD4 $\mathrm{T}$ cells, than the parental VRC01-resistant Envs. However, analysis of five VRC01-

${ }^{1} \mathrm{NIH} / \mathrm{NIAID}$, Bethesda, MD, USA

Full list of author information is available at the end of the article

resistant and four VRC01-sensitive autologous Envs from the VRC01 donor revealed no significant difference in replication kinetics or efficiency of CD4 usage in infectivity assays.

\section{Conclusion}

Some VRC01-resistant viruses appear to have impaired replicative fitness, possibly caused by reduced CD4mediated cell entry. However, VRC01-resistant Envs derived from the VRC01 donor did not display this deficiency, suggesting that compensatory changes over time may partially or fully restore CD4 usage and replication.

\section{Author details}

${ }^{1} \mathrm{NIH} / \mathrm{NIAID}$, Bethesda, MD, USA. ${ }^{2}$ The Scripps Research Institute, La Jolla, CA, USA. ${ }^{3}$ UCLA School of Medicine, Los Angeles, CA, USA.

Published: 13 September 2012

doi:10.1186/1742-4690-9-S2-P87

Cite this article as: Lynch et al:: Characterizing the fitness cost of viral escape from the HIV-1 broadly neutralizing monoclonal antibody VRC01. Retrovirology 2012 9(Suppl 2):P87.

Submit your next manuscript to BioMed Central and take full advantage of:

- Convenient online submission

- Thorough peer review

- No space constraints or color figure charges

- Immediate publication on acceptance

- Inclusion in PubMed, CAS, Scopus and Google Scholar

- Research which is freely available for redistribution

\section{Biomed Central}

(c) 2012 Lynch et al; licensee BioMed Central Ltd. This is an Open Access article distributed under the terms of the Creative Commons Attribution License (http://creativecommons.org/licenses/by/2.0), which permits unrestricted use, distribution, and reproduction in any medium, provided the original work is properly cited. 